\title{
Diabetes personalized: the use of whole-exome sequencing in order to identify familial type 2 diabetes mellitus susceptibility factors
}

\author{
Nehad Shaer', Jalaluddin J. Khan², Ashraf Dallol ${ }^{1 *}$, Adel Abuzenadah \\ From 2nd International Genomic Medical Conference (IGMC 2013) \\ Jeddah, Kingdom of Saudi Arabia. 24-27 November 2013
}

\section{Background}

Type 2 Diabetes Mellitus (T2DM) is a complex and pleomorphic metabolic disorder arising from a complex interaction between genes and the environment. However, the molecular landscape of T2DM is not fully explored, especially in a highly consanguineous society as the Saudi Arabian population [1]. Extended families could be predicted to cause an increase in the number and severity of genetic susceptibility factors for T2DM. We explore this hypothesis by applying whole-exome sequencing on four members of a Saudi family who all suffer from T2DM.

\section{Materials and methods}

Whole-exome sequencing of genomic DNA extracted from peripheral blood is performed on 3 brothers and their mother who are all suffering from confirmed T2DM. Sequencing was performed on the SOLiD 5500 XL platform at the Center of Excellence in Genomic Medicine Research, Jeddah, Saudi Arabia.

\section{Results}

We have identified novel mutations affecting SPRY2, ALPK2, ANXA4, and AGBL2 genes that could affect this family particularly susceptible to T2DM.

\section{Conclusions}

Whole-exome sequencing is very useful tool for detecting a large fraction of mutations, however, it cannot determine other genetic aberrations such as copy number and structural variations. However, finding novel mutations in a

\footnotetext{
* Correspondence: adallol@kau.edu.sa

${ }^{1}$ KACST Technology Innovation Center in Personalized Medicine, King

Abdulaziz University, Jeddah, KSA

Full list of author information is available at the end of the article
}

T2DM affecting genes such as SPRY2 may implicate these genes in diabetes.

\section{Authors' details}

${ }^{1}$ KACST Technology Innovation Center in Personalized Medicine, King Abdulaziz University, Jeddah, KSA. ${ }^{2}$ Department of Biochemistry, Faculty of Science, King Abdulaziz University, Jeddah, KSA.

Published: 2 April 2014

\section{Reference}

1. Ginter $E$, Simko V: Type 2 diabetes mellitus, pandemic in 21 st century. Adv Exp Med Biol 2012, 771:42-50.

\section{doi:10.1186/1471-2164-15-S2-P51}

Cite this article as: Shaer et al:: Diabetes personalized: the use of wholeexome sequencing in order to identify familial type 2 diabetes mellitus susceptibility factors. BMC Genomics 2014 15(Suppl 2):P51.

\section{() Biomed Central}

Submit your next manuscript to BioMed Central and take full advantage of:

- Convenient online submission

- Thorough peer review

- No space constraints or color figure charges

- Immediate publication on acceptance

- Inclusion in PubMed, CAS, Scopus and Google Scholar

- Research which is freely available for redistribution 